\title{
SUMMARY PLAN FOR BENCH-SCALE REFORMER AND PRODUCT TESTING TREATABILITY STUDIES USING HANFORD TANK WASTE
}

\author{
R.A.Robbins \\ Washington River Protection Solutions \\ Richland, WA 99352 \\ U.S. Department of Energy Contract DE-AC27-08RV14800

$\begin{array}{llll}\text { EDT/ECN: } & \text { DRF } & \text { UC: N/A } & \\ \text { Cost Center: } & \text { 2GF00 } & \text { Charge Code: } 200920 \\ \text { B\&R Code: } & 1111412 & \text { Total Pages: } & 22\end{array}$

Key Words: Fluidized-bed steam reforming, Bench-Scale Reformer, Treatability Study, Radioactive-Waste Shipment, Waste-Form Qualification

Abstract: This paper describes the sample selection, sample preparation, environmental, and regulatory considerations for shipment of Hanford radioactive waste samples for treatability studies of the FBSR process at the Savannah River National Laboratory and the Pacific Northwest National Laboratory.

TRADEMARK DISCLAIMER. Reference herein to any specific commercial product, process, or service by trade name, trademark, manufacturer, or otherwise, does not necessarily constitute or imply its endorsement, recommendation, or favoring by the United States Government or any agency thereof or its contractors or subcontractors.
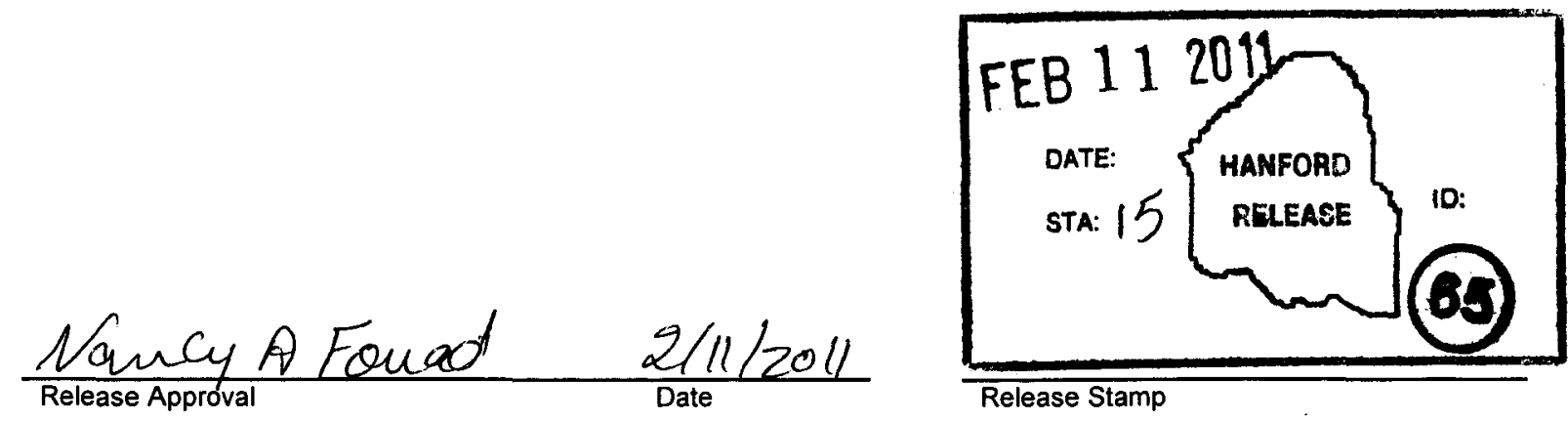

Approved For Public Release 


\begin{tabular}{|c|c|c|c|}
\hline \multicolumn{2}{|r|}{$\begin{array}{l}\text { Tank Operations Contractor (TOC) } \\
\text { RECORD OF REVISION }\end{array}$} & $\begin{array}{l}\text { (1) Document Number: } \\
\text { RPP-PLAN-47084 }\end{array}$ & Page 1 \\
\hline \multicolumn{4}{|c|}{$\begin{array}{l}\text { (2) Titie: } \\
\text { Summary Plan for Bench-Scale Reformer and Product Testing Treatability Studies Using Hanford Tank Waste }\end{array}$} \\
\hline \multicolumn{4}{|c|}{ Change Control Record } \\
\hline \multirow{2}{*}{$\begin{array}{c}(3) \\
\text { Revision }\end{array}$} & \multirow{2}{*}{ (4) Description of Change - Replace, Add, and Delete Pages } & \multicolumn{2}{|c|}{ Authorized for Release } \\
\hline & & (5) Resp. Engr. (print/sign/date) & (6) Resp. Mgr. (print/sign/date) \\
\hline 0 & Released with DRF $08 / 18 / 2011$ & J.B.Duncan & D.J.Swanberg \\
\hline $1 \mathrm{PS}$ & $\begin{array}{l}\text { - Page 1, paragraph 4, "objective of this paper" } \\
\text { changed to "objective of this summary plan" } \\
\text { Page 2, bullet 1, Requirements for the mass of } \\
\text { each sample shipment were changed to include } \\
\text { statement that facility conducting treatability } \\
\text { study cannot store more than 1000kg of "as } \\
\text { received" samples. } \\
\text { - Page 2, end of page, now says that roles and } \\
\text { responsibilities for study between Hanford and } \\
\text { SRNL are formalized in a "Memorandum of } \\
\text { Understanding." } \\
\text { Page 3, Figure 1, now includes additional step } \\
\text { "Hanford receives previously archived waste } \\
\text { forms from SRNL. Treatability study exemption } \\
\text { for archived material ends." } \\
\text { Page 6, now includes note establishing a } \\
\text { volume criteria for samples sent to SRNL (1L). }\end{array}$ & R.A.Robbins $02 / 03 / 2011$ & D.J.Swanberg $02 / 03 / 2011$ \\
\hline
\end{tabular}




\title{
SUMMARY PLAN FOR BENCH-SCALE REFORMER AND PRODUCT TESTING TREATABILITY STUDIES USING HANFORD TANK WASTE
}

\author{
J. B. Duncan \\ H. J. Huber \\ R. A. Robbins \\ D. J. Swanberg \\ Washington River Protection Solutions LLC
}

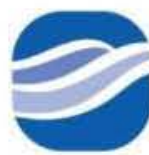

washington river protectionsolutions

Date Published

February 2011

Prepared for the U.S. Department of Energy

Office of River Protection

Contract No. DE-AC27-08RV14800 


\section{Table of Contents}

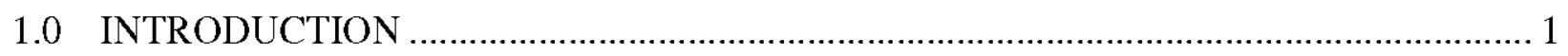

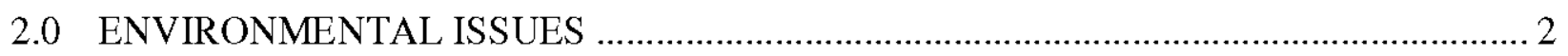

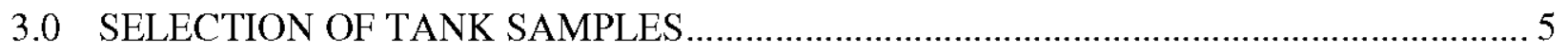

4.0 PREPARATION OF TANK SAMPLES FOR SHIPMENT ……………………............. 7

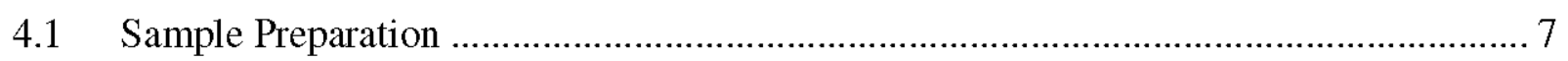

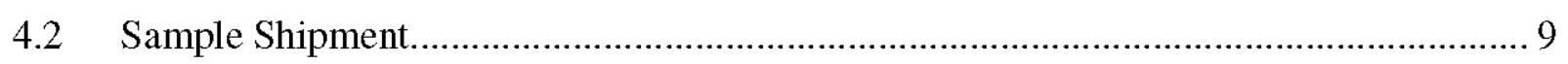

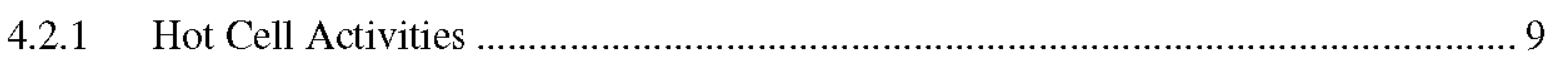

4.2.2 Department of Transportation Requirements................................................... 9

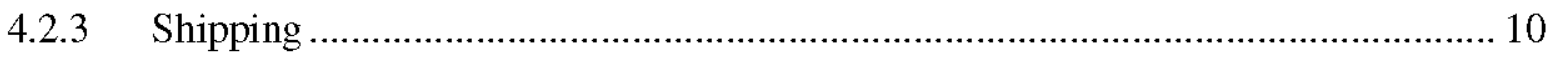

5.0 STEAM REFORMING PRODUCT AND PRODUCT TESTING ..................................... 11

5.1 Savannah River National Laboratory Testing ......................................................... 11

5.2 Pacific Northwest National Laboratory Testing .......................................................... 11

6.0 MATERIAL TO BE RETURNED FOR TESTING..................................................... 12

6.1 Disposition of Materials Generated by Savannah River National Laboratory............... 12

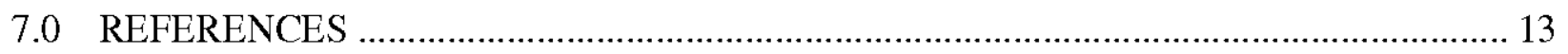

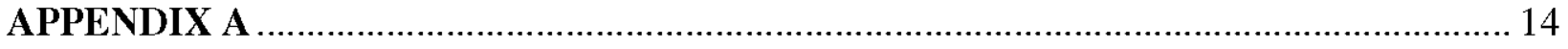

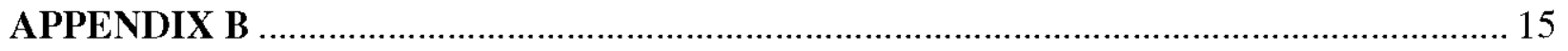

\section{List of Tables}

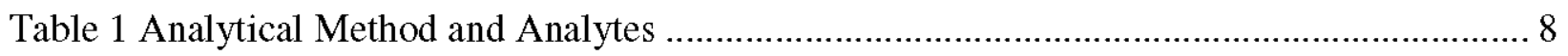

\section{List of Figures}

Figure 1 Steam Reforming Treatability Flow Chart ............................................................. 3

Figure 2. Material Compliance Obligations During Stages of Treatability Study ........................ 4

Figure 3 Sample Selection Logic Flow Chart ..................................................................... 5 


\section{List of Terms}

\section{Abbreviations}

AES

ALARA

ANSI

ASTM

ATL

BSR

CVAA

DOE

DOT

DQO

Ecology

EPA

FBSR

GEA

HLW

ICP

IDF

$\mathrm{kg}$

LAW

LCS

MS

NAS

NRC

PCB

PCT

$\mathrm{TcO}_{4}^{-}$

PNNL

PPE
Atomic Emission Spectroscopy

As Low As Reasonably Achievable

American National Standards Institute

American Society for Testing and Materials

Advanced Technologies and Laboratories International, Inc

Bench-scale Steam Reformer

Cold Vapor Atomic Adsorption

Department of Energy

Department of Transportation

Data Quality Objectives

Washington State Department of Ecology

Environmental Protection Agency

Fluidized Bed Steam Reformer

Gamma Energy Analysis

High-Level Waste

Inductively Coupled Plasma

Integrated Disposal Facility

Kilogram

Low-Activity Waste

Laboratory Control Sample

Mass Spectroscopy

Sodium-alumino-silicate

Nuclear Regulatory Commission

Polychlorinated biphenyl

Product Consistency Test

pertechnetate

Pacific Northwest National Laboratory

Personal Protective Equipment 
PUF

PVDF

QA

RPD

SEM

SCDHEC

SPFT

$\mathrm{Sr}$

SRNL

TCLP

TRU

TSD

TTT

U.S. DOE

WAC

WTP

XAS

XRD

XRF
Pressurized Unsaturated Flow Test

polyvinylidene fluoride

Quality Assurance

Relative Percent Difference

Scanning Electron Microscope

South Carolina Department of Health and Environmental Control

Single Pass Flow-Through Test

strontium

Savannah River National Laboratory

Toxicity Characteristic Leach Procedure

Transuranic

Treatment, Storage, Disposal

Thor Treatment Technologies

United States Department of Energy

Waste Acceptance Criteria

Hanford Waste Treatment and Immobilization Plant

X-Ray Absorption Spectroscopy

X-Ray Diffraction

$\mathrm{X}$-Ray Fluorescence

\section{Units}

$\mathrm{Kg} \quad$ Kilogram

M Molarity (moles/liter)

$\mathrm{mL} \quad$ Milli-liter $\left(1 \times 10^{-3} \mathrm{~L}\right)$

$\mu \mathrm{m} \quad$ Micro-meter $\left(1 \times 10^{-6} \mathrm{~m}\right)$

$\mu \mathrm{Ci} \quad$ Micro-curie $\left(1 \times 10^{-6} \mathrm{Ci}\right)$ 


\subsection{INTRODUCTION}

The U.S. Department of Energy (DOE) Hanford tank farms contain approximately 57 million gallons of wastes, most of which originated during the reprocessing of spent nuclear fuel to produce plutonium for defense purposes. DOE intends to pre-treat the tank waste to separate the waste into a high level fraction, that will be vitrified and disposed of in a national repository as high-level waste (HLW), and a low-activity waste (LAW) fraction that will be immobilized for on-site disposal at Hanford. The Hanford Waste Treatment and Immobilization Plant (WTP) is the focal point for the treatment of Hanford tank waste. However, the WTP lacks the capacity to process all of the LAW within the regulatory required timeframe. Consequently, a supplemental LAW immobilization process will be required to immobilize the remainder of the LAW.

One promising supplemental technology is Fluidized Bed Steam Reforming (FBSR) to produce a sodium-alumino-silicate (NAS) waste form. The NAS waste form is primarily composed of nepheline $\left(\mathrm{NaAlSiO}_{4}\right)$, sodalite $\left(\mathrm{Na}_{8}\left[\mathrm{AlSiO}_{4}\right]_{6} \mathrm{Cl}_{2}\right)$, and nosean $\left(\mathrm{Na}_{8}\left[\mathrm{AlSiO}_{4}\right]_{6} \mathrm{SO}_{4}\right)$. Semivolatile anions such as pertechnetate $\left(\mathrm{TcO}_{4}{ }^{-}\right)$and volatiles such as iodine as iodide (I) are expected to be entrapped within the mineral structures, thereby immobilizing them (Janzen 2008).

Results from preliminary performance tests using surrogates, suggests that the release of semivolatile radionuclides ${ }^{99} \mathrm{Tc}$ and volatile ${ }^{129} \mathrm{I}$ from granular NAS waste form is limited by Nosean solubility. The predicted release of ${ }^{99} \mathrm{Tc}$ from the NAS waste form at 100 meters down gradient well from the Integrated Disposal Facility (IDF) was found to be comparable to immobilized low-activity waste glass waste form in the initial supplemental LAW treatment technology risk assessment (Mann 2003). To confirm this hypothesis, DOE is funding a treatability study where three actual Hanford tank waste samples (containing both ${ }^{99} \mathrm{Tc}$ and ${ }^{125} \mathrm{I}$ ) will be processed in Savannah River National Laboratory's (SRNL) Bench-Scale Reformer (BSR) to form the mineral product, similar to the granular NAS waste form, that will then be subject to a number of waste form qualification tests. In previous tests, SRNL have demonstrated that the BSR product is chemically and physically equivalent to the FBSR product (Janzen 2005).

The objective of this summary plan is to describe the sample selection, sample preparation, and environmental and regulatory considerations for treatability studies of the FBSR process using Hanford tank waste samples at the SNRL. The SNRL will process samples in its BSR. These samples will be decontaminated in the 222-S Laboratory to remove undissolved solids and selected radioisotopes to comply with Department of Transportation (DOT) shipping regulations and to ensure worker safety by limiting radiation exposure to As Low As Reasonably Achievable (ALARA). These decontamination levels will also meet the Nuclear Regulatory Commission's (NRC's) definition of low activity waste (LAW). After the SNRL has processed the tank samples to a granular mineral form, SRNL and Pacific Northwest National Laboratory (PNNL) will conduct waste form testing on both the granular material and monoliths prepared from the granular material. The tests being performed are outlined in Appendix A. 


\subsection{ENVIRONMENTAL ISSUES}

Testing of Hanford tank waste samples using the BSR at SRNL will be considered a treatability study as defined by 40 CFR 260.10, 261.4, Protection of Environment and WAC 173-303, Dangerous Waste Regulations. Samples used for the purpose of treatability studies are classified as an "excluded category of waste" under WAC 173-303-071(3)(r).

Treatability study samples are excluded from a substantial portion of the regulatory requirements in WAC 173-303 during collection, preparation for transport, transport to the laboratory or testing facility, and transport of the remaining unused waste sample or FBSR waste form back to the original generator from the laboratory or testing facility, as long as the following requirements are met:

1. Mass of each sample shipment: The mass of a sample shipment from a generator must not exceed $1000 \mathrm{~kg}$. The facility conducting the treatability study may store no more than $1000 \mathrm{~kg}$ of "as received" treatability study samples (actual sample sizes will be limited to approximately $1 \mathrm{~L}$ ) (WAC 173-303-071(3)(r)(ii)(B) and (s)(iv)).

2. Packaging and Transport: The samples must be packaged so they will not leak, spill, or vaporize from their packaging during shipment and such that the transportation of each sample shipment complies with United States Department of Transportation (DOT) requirements.

3. Timeline for Shipping: Sample must be shipped, within 90 days of being generated or of being taken from a stream of previously generated waste, to a laboratory or testing facility which is exempt under WAC 173-303-071(s) or has an appropriate final facility permit or interim status.

4. Recordkeeping: The generator or sample collector maintains the following records for a period ending three years after completion of the treatability study:

A. Copies of the shipping documents;

B. A copy of the contract with the facility conducting the treatability study;

C. Documentation showing:

- The amount of waste shipped under this exemption;

- The name, address, and Environmental Protection Agency (EPA)/state identification number of the laboratory or testing facility that received the waste;

- The date the shipment was made; and

- Whether or not unused samples and FBSR waste form were returned to the generator.

D. The generator reports the 4.C. documentation above in its Dangerous Waste Annual Report due March 1 for the preceding calendar year (WAC 173-303-220(1)).

Figure 1 provides a basic flow diagram for meeting these requirements. Figure 2 depicts roles and responsibilities for implementation of treatability study activities between the Hanford Site and SRNL, which are formalized in a Memorandum of Understanding. 


\section{Figure 1 Steam Reforming Treatability Flow Chart}

Hanford Facility prepares samples for transport.

Sample preparation will include compositing and ion exchange to remove $\mathrm{Cs}$.

Sample preparation is conducted under the treatability Study Exemption (WAC 173-303$071(3)(r)(i)(A))$ however, the actual Treatability Study begins when samples are shipped

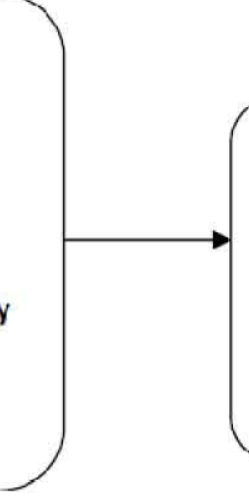

Hanford packages and ships samples to SRNL per DOT Regulations - Samples ship within 90 days of beginning sample preparation. One year treatability study time limit begins.

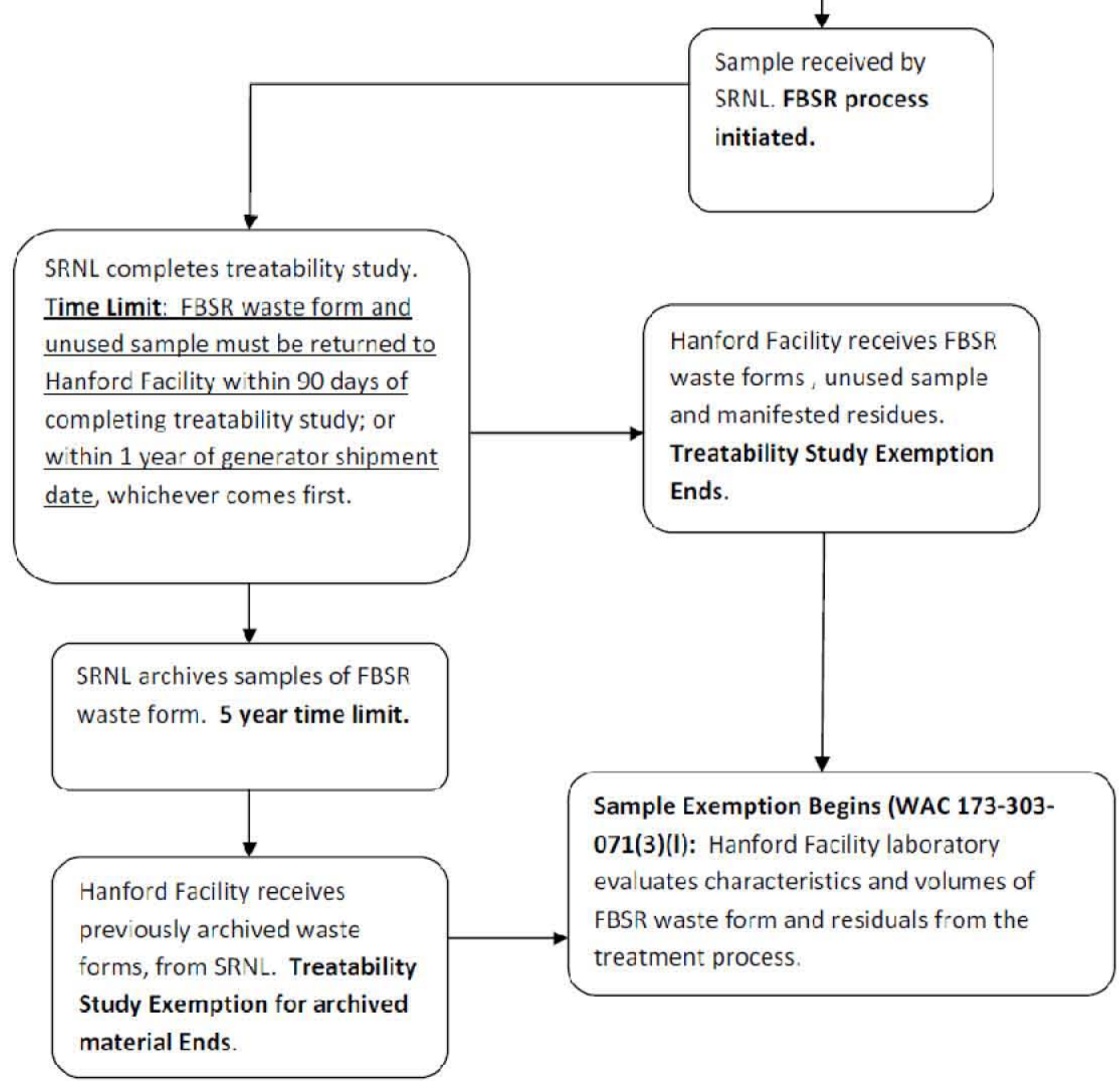


Figure 2. Material Compliance Obligations During Stages of Treatability Study

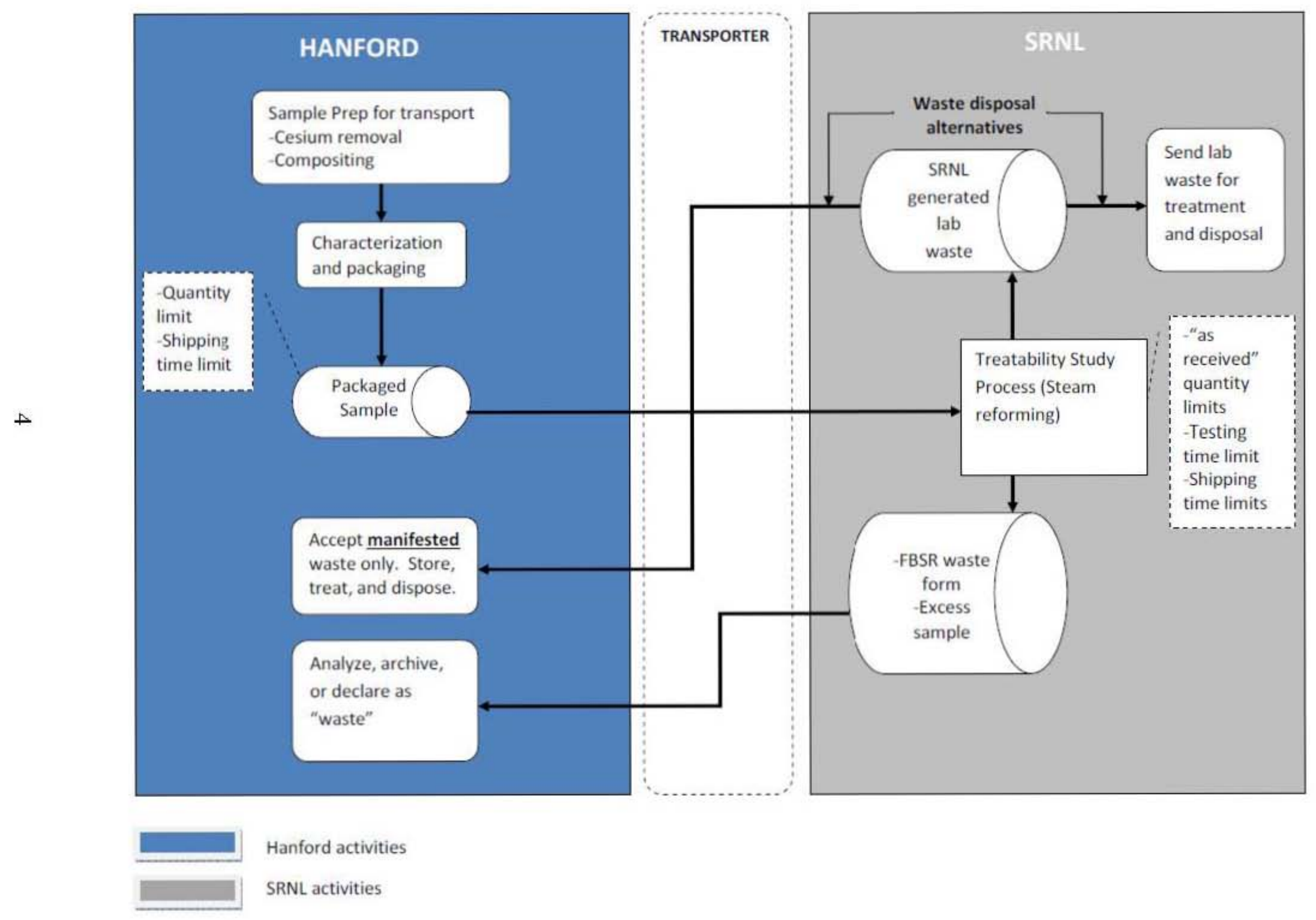




\subsection{SELECTION OF TANK SAMPLES}

The technical basis for the selection of candidate tank samples is described in RPP-RPT-47143, Sample Selection Recommendations for Fluid Bed Steam Reforming Treatability Studies Using Hanford Low Activity Waste Underground Storage Tank Samples, and in RPP-47073, Data Quality Objectives for Selecting Waste Samples to Test the Fluid Bed Steam Reformer Process.

The Data Quality Objectives (DQO) process is used to determine the type, quantity, and quality of data required to make a decision. It is the process employed in the selection of archived tank waste samples to be used for BSR process testing. Figure 3 is from RPP-47073 and shows the logic flow chart and decisions that will be made during the sample selection process.

As can be seen in Figure 3, the initial sample selection for BSR test samples is made using existing analytical data from archived tank samples in the 222-S Laboratory. The selected samples are analyzed and the results compared to test sample requirements and action limits outlined in RPP-47073. These data are used to determine if the selected samples are suitable for use as BSR test samples. The decisions to be made and the decision points in the selection process are shown in the logic flow chart in Figure 3.

\section{Figure 3 Sample Selection Logic Flow Chart}

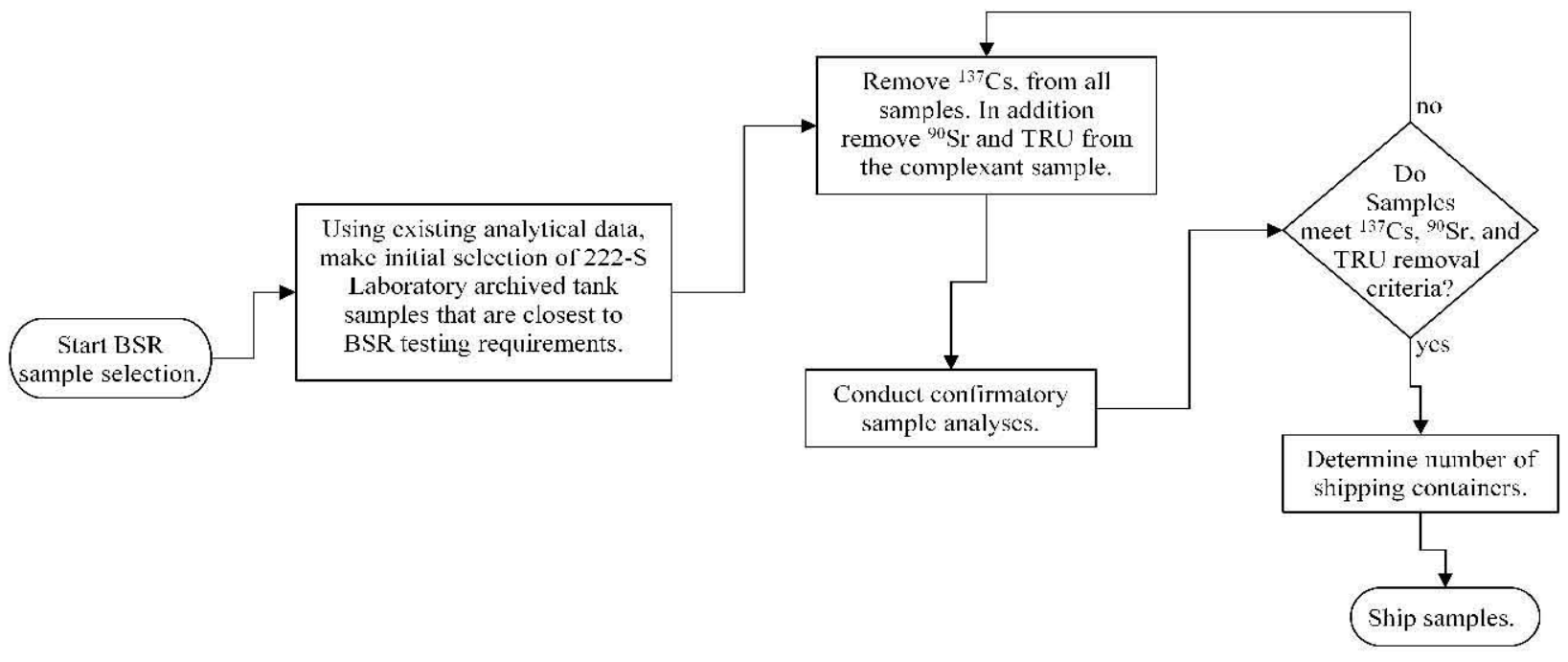


A number of criteria are used to select suitable radioactive waste samples:

- The samples should be representative of the bulk of the LAW to be treated and particular compositions of interest are:

- High sodium $(\mathrm{Na})$, low sulfate $\left(\mathrm{SO}_{4}{ }^{-2}\right)$, chloride $\left(\mathrm{Cl}^{-}\right)$, fluoride $\left(\mathrm{F}^{-}\right)$, and phosphate $\left(\mathrm{PO}_{4}{ }^{-3}\right)$ anions.

Low sodium (Na), high $\mathrm{SO}_{4}{ }^{-2}, \mathrm{Cl}^{-}, \mathrm{F}^{-}$, and $\mathrm{PO}_{4}{ }^{-3}$ anions ${ }^{1}$

- Complexant concentrate with other forms of $\mathrm{Tc}$ in solution besides pertechnetate $\left(\mathrm{TcO}_{4}^{-}\right)$

- Where possible, samples should be from tanks that represent tank waste likely to be processed by FBSR within the first 5-7 years of operations

- Samples should be those that have previously been included in vitrification studies

- Samples should be those that have previously been demonstrated in simulant FBSR trials.

Using these criteria, the tanks selected for samples from the archive to be shipped to SNRL are:

- Tank 241-SX-105 (saltcake)

- Tank 241-AN-103 (saltcake)

- Tank 241-AN-107 (complexant concentrate)

Approximately 1-liter of each sample will be sent to SRNL.

\footnotetext{
${ }^{1} \mathrm{It}$ is believed that anions such as $\mathrm{SO}_{4}{ }^{-2,} \mathrm{Cl}^{-}, \mathrm{F}^{-}$, and $\mathrm{PO}_{4}{ }^{-3}$ compete with pertechnetate $\left(\mathrm{TcO}_{4}\right)^{-}$for crystal locations
} within the NAS mineral structure 


\subsection{PREPARATION OF TANK SAMPLES FOR SHIPMENT}

\subsection{Sample Preparation}

As stated above, three tank samples have been identified from within the archived samples of the 222-S laboratory and will be prepared to meet the LAW requirements.

Laboratories and/or subcontracted laboratories performing analyses in support of this DQO shall have approved and implemented Quality Assurance (QA) Plans. These QA plans shall meet DOE/RL-96-68, Hanford Analytical Services Quality Assurance Requirements Documents (HASQARD) minimum requirements as the baseline for laboratory quality systems. Advanced Technologies and Laboratories, ATL-MP-1011, ATL Quality Assurance Project Plan for 222-S Laboratory specifies the analyses conducted at the 222-S Laboratory. Analyses performed by WRPS shall be performed by ATS-MP-1032, 222-S Laboratory Quality Assurance Plan.

The basic approach is to first adjust the identified samples to 5-7 $\mathrm{M} \mathrm{Na}$ concentration by diluting with water. The resulting solution will be inspected to determine if any solids are present, thus requiring filtration (As the strontium ( $\mathrm{Sr}$ ) and transuranic(TRU) components occur primarily in the solid phase, filtration will remove any $\mathrm{Sr}$ and TRU). The Sr and TRU concentrations of the sample are required to be minimized for LAW requirements as well as for ALARA and shipping reasons. If solids are present, the filter media, for the initial and subsequent filtration, will be a $0.45 \mu \mathrm{m}$ filter of polyvinylidene fluoride (PVDF) which is compatible with the tank samples from both radioisotope and highly alkaline aspects. After concentration adjustment and filtering (if required) each sample will be analyzed by sending an aliquot to the onsite analytical laboratory Advanced Technologies and Laboratories (ATL), International. Table 1 indicates the analytical methods and analytes. 
Table 1 Analytical Method and Analytes

\begin{tabular}{|c|c|c|c|c|c|}
\hline \multirow[b]{2}{*}{ Analytes } & \multicolumn{5}{|c|}{ Quality Control Acceptance Criteria } \\
\hline & $\begin{array}{l}\text { Proposed } \\
\text { Analytical } \\
\text { Methods }\end{array}$ & $\begin{array}{c}\text { LCS } \\
\text { \% Recovery } \\
\text { (a) }\end{array}$ & $\begin{array}{c}\text { Spike } \\
\% \text { Recovery }^{(b)}\end{array}$ & $\begin{array}{c}\text { Duplicate } \\
\text { RPD }^{(c)} \\
\text { Liquids }\end{array}$ & $\begin{array}{c}\text { Duplicate } \\
\text { RPD }^{(\mathrm{c})} \\
\text { Solids } \\
\end{array}$ \\
\hline $\begin{array}{c}\mathrm{Ag}, \mathrm{As}, \mathrm{Ba}, \mathrm{Be}, \mathrm{Cd} \\
\mathrm{Cr}, \mathrm{Hg}, \mathrm{Pb}, \mathrm{Na}, \mathrm{Ni} \\
\mathrm{Sb}, \mathrm{Se}, \mathrm{Tl}, \mathrm{V}, \mathrm{Zn}\end{array}$ & ICP/AES & $80-120$ & $75-125$ & $\leq 20 \%$ & $\leq 30 \%$ \\
\hline $\mathrm{Cl}^{-}, \mathrm{F}^{-}, \mathrm{PO}_{4}^{3-}, \mathrm{SO}_{4}^{2-}$ & IC & $80-120$ & $75-125$ & $\leq 20 \%$ & $\leq 30 \%$ \\
\hline${ }^{90} \mathrm{Sr}$ & Beta Counting & $80-120$ & $\mathrm{~N} / \mathrm{A}^{(\mathrm{d})}$ & $\leq 20 \%$ & $\leq 30 \%$ \\
\hline $\begin{array}{c}{ }^{241} \mathrm{Am},{ }^{243} \mathrm{Am},{ }^{238} \mathrm{Pu}, \\
{ }^{239} \mathrm{Pu},{ }^{240} \mathrm{Pu},{ }^{242} \mathrm{Pu}, \\
{ }^{244} \mathrm{Pu},{ }^{237} \mathrm{~Np},{ }^{229} \mathrm{Th}, \\
{ }^{230} \mathrm{Th},{ }^{232} \mathrm{Th},{ }^{231} \mathrm{~Pa}, \\
{ }^{233} \mathrm{U},{ }^{234} \mathrm{U},{ }^{235} \mathrm{U},{ }^{236} \mathrm{U}, \\
{ }^{238},\end{array}$ & ICP/MS & $80-120$ & $75-125$ & $\leq 20 \%$ & $\leq 30 \%$ \\
\hline${ }^{99} \mathrm{Tc}$ & $\begin{array}{c}\text { Liquid } \\
\text { Scintillation }\end{array}$ & $80-120$ & $75-125$ & $\leq 20 \%$ & $\leq 30 \%$ \\
\hline${ }^{137} \mathrm{Cs}$ & GEA & $80-120$ & $\mathrm{~N} / \mathrm{A}^{(\mathrm{e})}$ & $\leq 20 \%$ & $\leq 30 \%$ \\
\hline TOC & $\begin{array}{l}\text { Silver catalyzed } \\
\text { persulfate } \\
\text { oxidation }\end{array}$ & $80-120$ & $75-125$ & $\leq 20 \%$ & $\leq 30 \%$ \\
\hline
\end{tabular}

Notes:

N/A = Not Applicable

$\mathrm{TOC}=$ total organic carbon

(a) LCS = Laboratory Control Sample. This sample is carried through the entire method. The accuracy of a method is usually expressed as the percent recovery of the LCS. The LCS is a matrix with known concentration of analytes processed with each preparation and analyses batch. It is expressed as percent recovery; i.e., the amount measured, divided by the known concentration, times 100 .

(b) For some methods, the sample accuracy is expressed as the percent recovery of a matrix spike sample. It is expressed as percent recovery; i.e., the amount measured, less the amount in the sample, divided by the spike added, times 100 . One matrix spike is performed per analytical batch. Samples are batched with similar matrices.

(c) RPD = Relative Percent Difference between the analytical samples. Analytical precision is estimated by analyzing duplicates taken separately through preparation and analysis. RPD for Polychlorinated biphenyl (PCBs) may be calculated using matrix spike and matrix spike duplicate results. Acceptable analytical precision is usually $\leq 20 \%$ RPD for liquids and $\leq 30 \%$ for solids, if the sample result is at least 10 times the instrument detection limit.

$$
\mathrm{RPD}=((\text { absolute difference between primary and duplicate }) / \text { mean }) \times 100
$$

(d) Matrix spike analyses are not required for this method because a carrier or tracer is used to correct for constituent loss during sample preparation and analysis. The result generated using the carrier or tracer accounts for any inaccuracy of the method on the matrix. The reported results reflect this correction.

(e) The measurement is a direct reading of the energy and the analysis is not affected by the sample matrix; therefore, a matrix spike is not required. 
Each sample will then be contacted with a cesium sorbent such as IONSIV ${ }^{2}$ IE-911 or spherical Resorcinol Formaldehyde to remove radioactive cesium. An aliquot will be submitted to ATL for cesium analysis. When the radioactive cesium level is at the concentration agreed upon, then any additional $\mathrm{Sr}$ and TRU removal will proceed, if required.

Strontium and TRU will be removed from the tank 241-AN-107 complexant concentrate sample using the protocol reported by Nash, et al. in Separation Science and Technology, 2003. The protocol uses a non-radioactive $1 \mathrm{M}$ strontium nitrate and a $1 \mathrm{M}$ sodium permanganate solution, which is consistent with the strontium and TRU removal step in the current WTP flowsheet.

When the reaction is complete, an aliquot will be submitted to ATL to determine the success of the operation.

Conceptual flow sheets are presented in Appendix B.

\subsection{Sample Shipment}

The tank samples identified for the treatability studies will be prepared for packaging and shipment after filtration and cesium removal by sorbent/ion exchange processes. The complexant tank sample will be prepared for packaging and shipment after filtration and removal of $\mathrm{Cs}, \mathrm{Sr}$, and TRU radioisotopes. Shipment will occur via ground transportation and will commence no sooner than 45 days after SRNL has sent notification to the South Carolina Department of Health and Environmental Control (SCDHEC).

\subsubsection{Hot Cell Activities}

In order to prepare samples for shipping, a determination is made as to the dose rate of the sample. Once the dose rate is determined, a sample container size $(125 \mathrm{~mL}, 250 \mathrm{~mL}$ or $1 \mathrm{~L})$ will be identified for shipping. The material will be packaged in accordance with the Hedgehog operating manual: HNF-11651, Operation and Maintenance Manual for the Hedgehog II Packaging System. The laboratory will package using procedure LO-090-157, Preparation/Loading of Type A Hedgehog II Packaging for Shipment, and LO-090-156, Tighten/Torque and Quality Control Verify Type A Packaging for Shipment.

\subsubsection{Department of Transportation Requirements}

The samples will be packaged and shipped as Type A shipments per 49 CFR 173 .

The laboratory data needed to support the shipment are:

- Activity per isotope, $\mu \mathrm{Ci} / \mathrm{mL} ; \mu \mathrm{Ci} / \mathrm{g}$, etc.

- The sample weight

- The sample phase (solid or liquid)

- Sample dose at contact, at 1 meter

- Exact address at SNRL

- Contact person at SRNL, name, email, and phone number

${ }^{2}$ IONSIV $^{\circledR}$ is a registered trademark of Universal Oil Products, Inc., Des Plaines, Illinois. 


\subsubsection{Shipping}

Approval to ship will be provided by the Certified Hazardous Material Shipper (Eugene Juteau or delegate) once all appropriate approvals are in place at Hanford and SRNL.

A commercial shipping subcontractor will physically transport the samples to the SNRL as an "exclusive use" shipment. The configuration will most likely be a standard 40 foot enclosed van with tractor. The estimated time of delivery for team drivers is 2.5 days. 


\subsection{STEAM REFORMING PRODUCT AND PRODUCT TESTING}

\subsection{Savannah River National Laboratory Testing}

SRNL will conduct a number of BSR tests on each of the Hanford LAW samples using the mineralizing flowsheet to produce an alkali aluminosilicate granular product in conjunction with Thor Treatment Technology (TTT) oversight as prescribed in DOE's contract DE-AC0906SR22521, to ensure proper application of their proprietary technology. Data will be gathered during the operational radioactive BSR runs and equipment smears taken to ascertain the partitioning of key elements (for example, ${ }^{137} \mathrm{Cs},{ }^{99} \mathrm{Tc}$, and ${ }^{129} \mathrm{I}$ ) between the solid product and the off-gas. A portion of the granular product from each of the Hanford LAW samples will be immobilized in a geopolymer matrix to form a monolith. A number of performance tests will be carried out on the radioactive granular and monolithic product samples including the Product Consistency Test (PCT). Additional data will be gathered from redox measurements, X-ray Defraction (XRD), X-ray Fluorescence (XRF), Scanning Electron Microscope (SEM), and other analytical techniques as required. Compressibility strength tests will also be performed on the radioactive monoliths.

Radioactive samples of both the granular and monolith products will be sent to PNNL for further tests (see below)

\subsection{Pacific Northwest National Laboratory Testing}

PNNL will conduct a number of measurements on the LAW BSR product being produced at SRNL. The objective of the selected tests is to address the following issues:

- Identify the key reactions and/or processes affecting waste form durability and contaminant release

- Quantify the extent and rate of these reactions and/or processes

- Obtain the model parameters needed to describe these reactions and/or processes to better predict the behavior of the system

- Verification of the derived model parameters

These measurements will include the use of spectroscopic characterization techniques to evaluate technetium speciation and single-pass flow-through experiments to determine kinetic rate law parameters, effect of solution composition on the dissolution of granular and monolith BSR product, and effect of the binder on contaminant release from the BSR product. PNNL will also conduct the Toxicity Characteristic Leach Procedure (TCLP) and product consistency test (PCT) (duplication) for leachability, and the pressurized unsaturated flow (PUF) test. In addition, a combination of x-ray diffraction, scanning and/or transmission electron microscopy, and/or x-ray photoelectron spectroscopy, will be used characterize these radioactive samples. 


\subsection{MATERIAL TO BE RETURNED FOR TESTING}

\subsection{Disposition of Materials Generated by Savannah River National Laboratory}

The SRNL is expected to generate materials from conducting FBSR activities that can be categorized as a FBSR waste form, unused samples, laboratory samples, or residues. For the purposes of this section: "FBSR waste form" means Hanford tank waste samples that have been treated by the steam reforming process under the treatability study sample exclusion and "residues" means all other materials produced by the treatability studies, e.g., laboratory equipment, personal protective equipment, that is contaminated by contact or co-mingling with Hanford generated tank wastes that are not FBSR waste form or unused samples.

A portion of the FBSR waste form either in granular or monolithic form will be transported to PNNL for testing. FBSR waste form and unused Hanford tank waste samples may be returned to the Hanford site under the treatability study exclusion upon prior approval from DOE-ORP.

Residues as described above including laboratory generated materials such as contaminated equipment and personal protective equipment (PPE) shall be dispositioned by SRNL and shall not be returned to Hanford under the treatability study sample exclusion. SRNL shall not return any residues as described above to Hanford except upon express prior approval from DOE-ORP. 


\subsection{REFERENCES}

40 CFR 260.10, 261.4, "Protection of Environment", Code of Federal Regulations as amended.

49 CFR Part 173, "Shippers -General Requirements for Shipping and Packaging," Code of Federal Regulations, as amended.

AC 173-303, "Dangerous Waste Regulations," as amended, State of Washington.

ATL-MP-1011, 2009. Rev 9, ATL Quality Assurance Project Plan for 222-S Laboratory, 222-S Laboratory, Advanced Technologies and Laboratories International, Inc., Richland, Washington.

ATS-MP-1032, 2010, Rev 4, 222-S Laboratory Quality Assurance Plan, 222-S Laboratory, Washington River Protection Solutions, Richland WA.

DE-AC09-06SR22521 Contract, Thor Treatment Technologies, LLC Aiken, South Carolina.

Jantzen, C.M., "Evaluation of Fluidized Bed Steam Reforming (FBSR) Technology for Sodium Bearing Wastes from Idaho and Hanford Using the Bench-Top Steam Reformer (BSR)", WSRC-TR-2004-00560, 2005.

Jantzen, C.M., "Mineralization of Radioactive Waste by Fluidized Bed Steam Reforming: Comparison to Vitreous Waste Forms, and Pertinent Durability Testing," WSRC-STI2008-00268, 2008.

Nash, C. A., H.H. Soto and W.R. Wilmarth, "Strontium and Transuranic Precipitation and Crossflow filtration of a Large Hanford Tank 241-AN-102 Sample, Separation Science and Technology," 38(12\&13):3189-3213, 2003.

HNF-11651, 2007, Rev 1, Operation and Maintenance Manual for the Hedgehog II Packaging System, CH2M Hill Hanford Group, Inc., Richland, Washington.

LO-090-156, 2009, “Tighten/Torque and Quality Control Verify Type A Packaging for Shipment," Rev E-0, Advanced Technologies and Laboratories International, Inc., Richland, Washington.

LO-090-157, 2009, "Preparation / Loading of Type A Hedgehog II Packaging for Shipment," Rev B-0, Advanced Technologies and Laboratories International, Inc., Richland, Washington.

ORP-11242, R 4, 2009, River Protection Project System Plan, US DOE Office of River Protection, Richland, Washington.

RPP-PLAN-47143, 2010 Sample Selection Recommendations for Fluid Bed Steam Reforming Treatability Studies Using Hanford Low Activity Waste Underground Storage Tank Samples, Washington River Protection Solutions, Richland, Washington

RPP-47073, 2010, Data Quality Objectives for Selecting Waste Samples to Test the Fluid Bed Steam Reformer Process, Washington River Protection Solutions, Richland, Washington.

RPP-17675, Rev. 0, 2003, Risk Assessment Supporting the Decision on the Initial Selection of Supplemental ILAW Technologies, CH2MHILL Hanford Group Inc., Richland, Washington 


\section{APPENDIX A}

\section{Steam Reforming Waste Form Tests}

\section{Savannah River National Laboratory (SRNL)}

All the radioactive Hanford LAW samples will be subjected to:

- Processing through the bench-scale reformer run to produce a granular product

- Production of ten (10) 1"diameter by 2" cylindrical monoliths from granular product

The following tests will be performed on the granular and/or monolithic product from the radioactive BSR runs:

- Mineral characterization (Redox, XRD, XRF, SEM etc.)

- Short-term and long-term product consistency test (PCT) (ASTM C-1285)

- Compressive strength (ASTM-C-39/C39M-99)

Note: Any analyses that require a third party, off-site laboratory will be managed by PNNL. Samples requiring these analyses will be sent to PNNL and they will contract with the appropriate laboratory.

\section{Pacific Northwest National Laboratory (PNNL)}

Savannah River National Laboratory will ship samples of the granular product and the monolith formed from BSR processing of each of the radioactive Hanford LAW samples. PNNL will conduct the following tests on the granular and/or monolithic product:

- Single Pass Flow-Through (kinetic rate information)

- Pressurized Unsaturated Flow (PUF)

- Short-term and long-term product consistency test (PCT) (ASTM C-1285) - duplication

- Tc and Re speciation

- Measurement of thermodynamic constants (subcontracted to UC Davis)

- Mineral characterization (micro-XRD, XAS)

- Toxicity Characteristic Leach Procedure (TCLP) in accordance with SW-846

- Waste Package Release Testing (ANSI/ANS 16.1, EPA draft method 1315, or ASTM C1308) Monolith diffusion testing (ASTM 1308, EPA 1315 or ANSI 16.1)

Note: Duplicate tests (e.g., short and long-term PCT) may be carried out at either laboratory 


\section{APPENDIX B}

\section{Conceptual Flow Sheets for Sample Preparation}

Diluent addition for

Figure B-1. Saltcake Dissolution Flowsheet.

salt cake dissolution

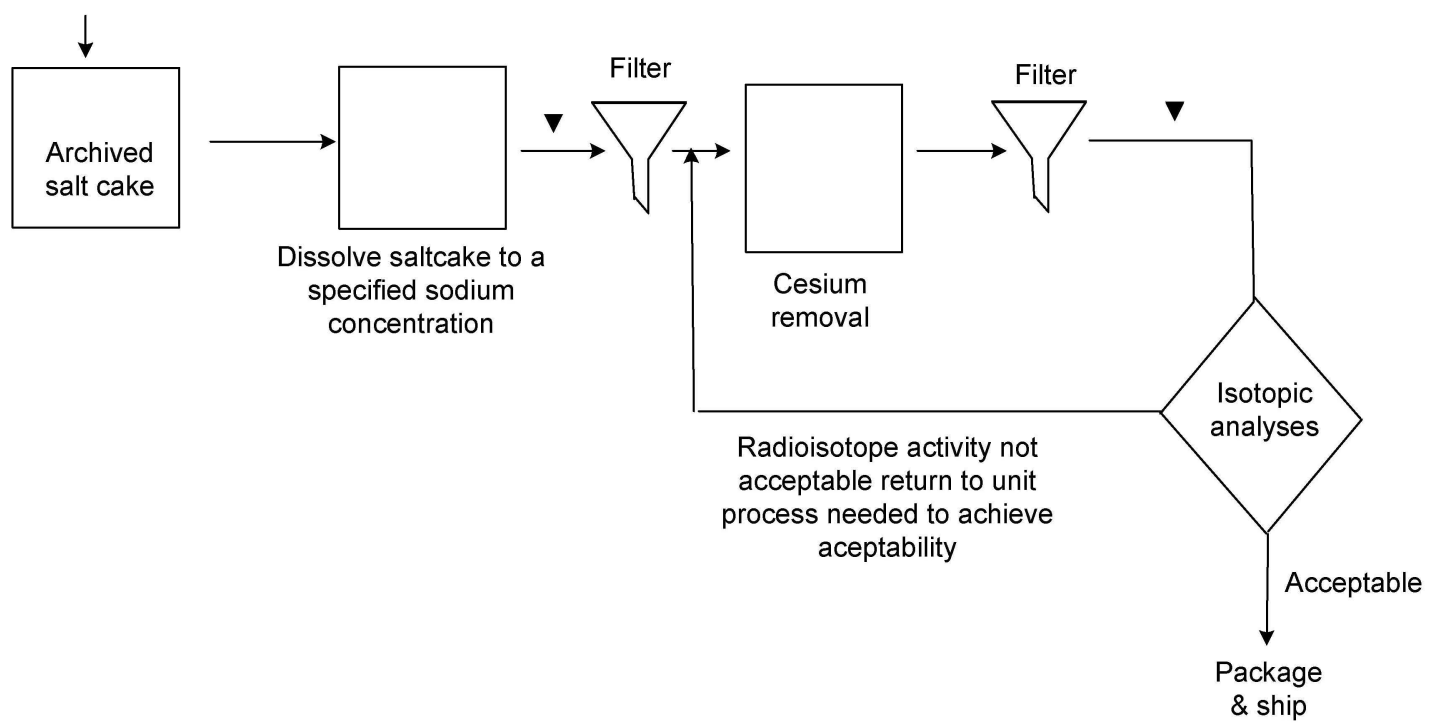

Note: The primary analysis of interest to pack and ship is the isotopic analyses. An aliquot for a full suite of analyses is taken where the symbol $(\nabla)$ indicates. These analyses are not needed for packaging and shipping and will be sent to SRNL upon completion.

Figure B-2. Cesium, Strontium, TRU Removal Flowsheet.

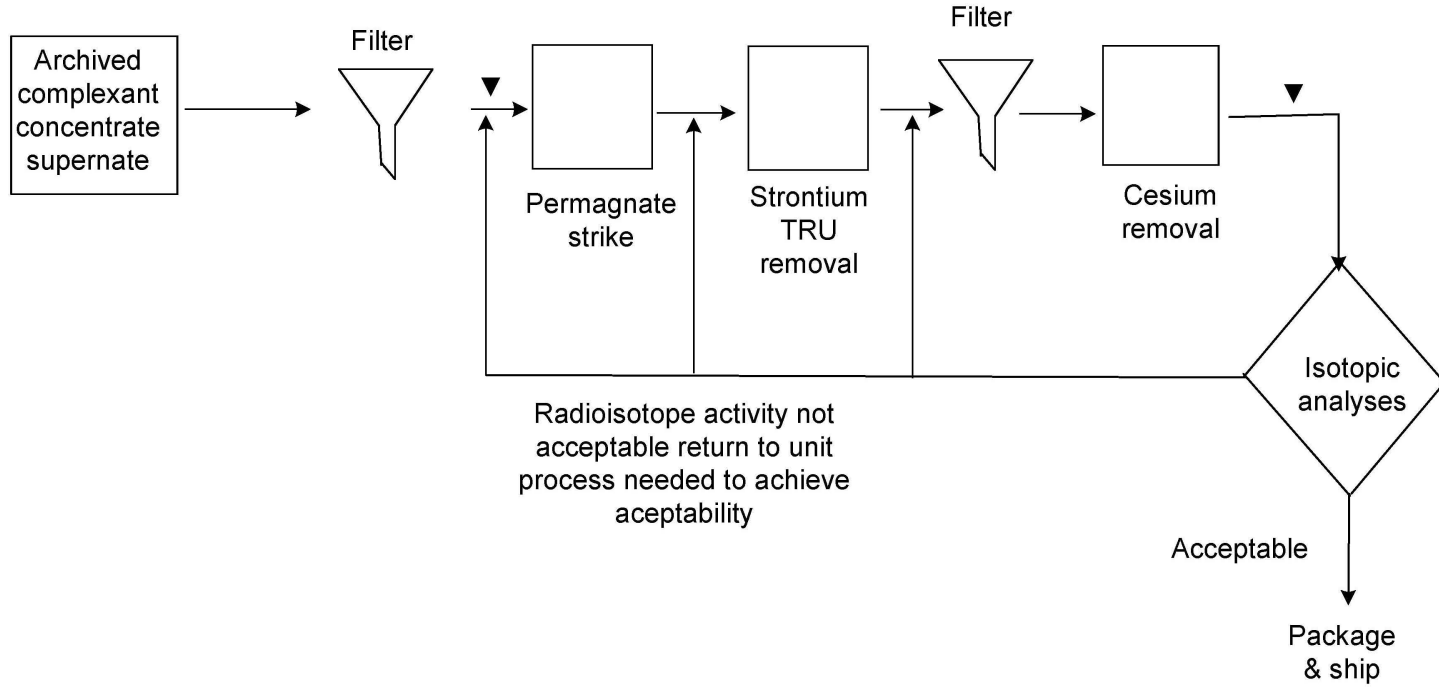

Note: The primary analysis of interest to pack and ship is the isotopic analyses. An aliquot for a full suite of analyses is taken where the symbol $(\nabla)$ indicates. These analyses are not needed for packaging and shipping and will be sent to SRNL upon completion. 